\title{
Miasto-poza-miastem. Przejawy współczesnego flâneuryzmu w medium gry wideo ${ }^{1}$
}

Współcześnie miasto stało się dla człowieka środowiskiem naturalnym. Jego struktura to konglomerat złożony nie tylko z architektonicznych brył i mieszkających w nim ludzi. To również przestrzeń kulturowa nasycona bezustannym przepływem artefaktów, znaczeń i idei, która znacząco wykracza poza ramy swojej fizyczności. Miasto to ciągle zmieniający się, często w sposób nieprzewidywalny, żywy organizm. Jest dzięki temu niewyczerpalnym źródłem inspiracji dla artystów. W jego granicach realizowane są przeróżne praktyki twórcze, mające na celu sproblematyzowanie, wydobycie na powierzchnię wszelkich mechanizmów i procesów, które sprawiają, że to przestrzeń tak wyjątkowa. Swoje granice miasto przekracza również realizując swoją ideę między innymi w literaturze czy filmie. W tym kontekście wydaje się jednak, że to właśnie gry wideo są medium szczególnym dla reprezentacji miasta. Pozwalają one bowiem, by idea miasta, przetłumaczona na język przestrzeni wirtualnej, zmaterializowała się w nowej formule. Gry nie skupiają się jedynie na przedstawianiu jego fizyczno-estetycznej powłoki, czy też symulacji panujących w nim stosunków społecznych, ale pozwalają graczowi również na taktylne przeżycie struktury miasta. Idea staje się realnością, a co za tym idzie, podczas eksploracji środowiska gry wideo wyzwolone zostają te same mechanizmy i strategie znane z miejskiej codzienności. Ponadto specyfika przestrzeni gry sprawia, że ten rodzaj doświadczenia wcale nie musi ograniczać się

1 Artykuł zawiera fragmenty pracy magisterskiej, która powstawała w latach 2011-2013 w Instytucie Sztuk Audiowizualnych Uniwersytetu Jagiellońskiego pod kierunkiem prof. dr. hab. Andrzeja Pitrusa. 
do przestrzeni wizualnie przypominającej miasto. Dlatego też można pewne typowo miejskie zjawiska, jak właśnie flâneuryzm, zaobserwować również w takich grach jak Proteus [Key i Kanaga 2013] czy Dear Esther [The Chinese Room 2012], gdzie eksplorujemy niezamieszkałe, niedotknięte cywilizacją wyspy.

\section{Narracja w ruchu}

Miasto, jako naturalne środowisko gracza, jest przestrzenią znajomą i czytelną. Jest też idealną dla gry wideo ze względu na swoją strukturę: to w zdecydowanej większości przykładów przestrzeń zamknięta, całościowa i niezależna. Ponadto obie przestrzenie, miejską i tą wirtualną, łączy doświadczenie ruchu. To właśnie on sprawia, że ożywają. Z każdym krokiem budowane są nowe znaczenia, które wydobywają narracyjny potencjał ukryty w przestrzeni. Człowiek codziennie odbywa podróże, tworząc swoje małe i wielkie historie. Odwiedza miejsca znane, często intymne, które bezpośrednio odwołują się do jego wspomnień. Podejmuje również trud odwiedzenia przestrzeni całkiem obcych, by dzięki temu je oswoić i przypisać własne znaczenia. Dać im szansę stać się bliskimi. Człowiek buduje narrację swojej tożsamości poprzez bycie aktywnym uczestnikiem przestrzeni.

Nietrudno zatem zauważyć, że obok historii budowanej przez wszelkie dialogi, przerywniki fabularne oraz teksty, które gracz może znaleźć wewnątrz świata gry, potrzebne są jeszcze inne elementy pomagające wykreować dobrą opowieść. Jednym z nich jest właśnie ruch, ponieważ każda historia zaczyna się już w czasie pierwotnej eksploracji, momencie wyboru i organizacji przestrzeni [Dovey i Kennedy 2011, 123]. Dzieje się tak, ponieważ opowieść w grze, podobnie jak miasto, jest kompozycją bardziej przestrzenną, niż fabularną. Na różnych poziomach gry można przemycić fragmenty historii i jedynie od gracza zależy, jak głęboko się w nią zanurzy. Pokrywa się to z myślą Henry'ego Jenkinsa [2004, 121], który pisząc o sposobach opowiadania przestrzenią, stwierdza, że projektant gry jest bardziej architektem narracji niż pisarzem fabuł. To samo dotyczy zarówno pieszego, jak i gracza, którzy w swoich przestrzeniach tkają narracyjną siatkę zdarzeń.

Ludzka aktywność zbudowana jest przede wszystkim na doświadczeniu przestrzeni. Przy tym każdy z ludzkich zmysłów jest tak samo ważny i dopiero wspólne wrażenia mogą dać pełen ogląd rzeczywistości. Ponadto, jak pisze Yi-Fu Tuan $[1978,31]$ :

Podmiot lub miejsce zyskuje konkretną realność, jeśli doświadczamy go w sposób totalny, to znaczy wszystkimi zmysłami oraz aktywną i refleksyjną myślą. 
Całość ludzkiego doświadczenia, zmysłowego i mentalnego, składa się na prawdziwe przeżycie rzeczywistości. Opowieści rodzą się wraz z dynamiką ludzkich kroków. Będąc w wiecznym ruchu, odbieramy sygnały ze środowiska i wokół tej wiedzy budujemy nasze rozumienie świata ${ }^{2}$. Jak pisze Michel de Certeau [2008, 99]: „akt chodzenia jest dla systemu miejskiego tym, czym wypowiadanie (speech act) jest dla języka lub zrealizowanych wypowiedzeń”. Dzieje się tak na różnych poziomach: pieszy zawłaszcza topografię (podobnie jak mówiący robi z językiem); zakłada się, że między pieszym a innymi podmiotami dochodzi do relacji, która przypomina zawarcie umowy (jak między współrozmówcami); wreszcie - chodzenie jest realizacją miejsca (jak język realizuje się podczas aktu mowy). Zwracając uwagę na ten ostatni aspekt - chodzący odczytuje przestrzeń za każdym razem na nowo. A jako, że jest ona zbiorem możliwości i zakazów, to nadawanie znaczeń jest intuicyjnie łatwe. Za każdym razem, gdy człowiek wybiera swoją trasę, nagle zmienia jej przebieg lub po prostu błąka się $\mathrm{w}$ pieszej improwizacji, dokonuje zmiany przestrzennego signifiant $\mathrm{w}$ coś zupełnie nowego. W ten sposób odkrywane są nowe „wyrażenia”, podczas gdy stare skazywane są tym samym na zapomnienie [de Certeau, 99-100]. Przestrzeń jest w ruchu, by historia mogła zostać wypowiedziana. W mieście, gdzie przestrzeń jest zaprojektowana przez człowieka dla człowieka, opowieści snują się najintensywniej. Dlatego też tożsamość przestrzeni miejskiej z przestrzenią gry jest tak wyraźna i mocna. Gracz, tak jak pieszy wydeptujący swoje ścieżki, „wypowiada” przestrzeń gry. Odciska na niej piętno swojego grania, chociaż wcale nie musi tym samym przeciwstawiać się zasadom. Nadaje nowy wymiar nawet jednoliniowym fabułom.

Jest to możliwe, ponieważ przestrzeń gry opiera się przede wszystkim na doświadczeniu, a nie jedynie reprezentacji przestrzeni. Filmowiec prezentuje widzowi wizję świata, samą ideę jego doświadczenia. Natomiast projektant przestrzeni stara się stworzyć odpowiednie warunki, by gracz mógł zaznać pełnowymiarowego doświadczenia. Nie pokazuje on jedynie pewnej wizji, a raczej pomaga odkryć rzeczywistość samą w sobie [Nitsche 2008, 57]. Gracz poznaje przestrzeń gry w ruchu swojego awatara. Oczywiście doświadczenie to może być uznane za niepełne. Nie należy jednak zapominać o immersyjności przestrzeni wirtualnej, która uaktualnia się w grach dzięki technologii oraz umiejętnej prezentacji świata wspomaganego przez dobrze skonstruowaną estetykę oraz rozgrywkę. W dobrze zaprojektowanej rzeczywistości gracz jest w stanie w pełni się zanurzyć, opierając swoje wrażenie na zdobytym już

2 Takie podejście do poznania jest podstawą nurtu enaktywizmu w filozofii kognitywnej. W kontekście powyższego artykułu warto przyjrzeć się pracom Evana Thompsona, Alvy Noë czy Marieki Rohde. 
doświadczeniu. Ponadto łatwo zauważyć, że ruch gracza w środowisku wirtualnym jest intuicyjny. Opiera się on na schematach, których człowiek używa na co dzień poruszając się po mieście. Tożsama jest zarówno podstawowa mechanika ruchu, jak i strategie potrzebne do badania środowiska. Dotyczy to na przykład pokonywania wszelkich barier: od zwykłego otworzenia drzwi po spektakularną wspinaczkę. Podobnie jest $\mathrm{z}$ zastosowaniem przedmiotów, którymi gracz musi się nauczyć posługiwać. Oczywiście trzeba tutaj wziąć pod uwagę zwykle ograniczone możliwości człowieka względem tego, co potrafią bohaterowie gier W samej zasadzie jednak nie ma istotnej różnicy.

Trudno tutaj nie wspomnieć o mentalno-afektywnym aspekcie tworzonej przez człowieka rzeczywistości, w której emocje i wspomnienia mają bezpośredni wpływ na codzienne doświadczenie świata. Człowiek każdego dnia porusza się kierując się wewnętrznymi mapami mentalnymi. Pojęcie to zostało przybliżone przez Kevina Lyncha [1960], dla którego mapy mentalne są złożonymi interpretacjami przestrzeni realnej i fikcyjnej. Powstają w strukturach naszego umysłu z sumy wszystkich doświadczeń, zarówno tych zmysłowych, jak i pozazmysłowych. Konstruowane są z informacji prawdziwych, mających potwierdzenie w faktach, oraz fikcyjnych, które są sumą fantastycznych wyobrażeń. Szeregują zjawiska w przestrzeni i sytuują człowieka względem nich, ponieważ: „nic nie może być doświadczone samo przez się, a jedynie w relacji do swojego otoczenia" [Lynch, 1]. Mentalne postrzeganie przestrzeni wpływa również na poczucie odległości, stąd wrażenie, że znana droga wydaje się krótsza, niż taki sam dystans na obcym terenie. Takie deformacje przestrzeni fizycznej nie wpływają jednak w żaden sposób na efektywne poruszanie się w niej. Wręcz przeciwnie - subiektywne oswojenie przestrzeni umożliwia sprawniejszą eksplorację.

W grach wideo człowiek również kieruje się takimi wewnętrznymi mapami, chociaż cała przestrzeń jest już narzucona, a stawiane wybory okazują się być często iluzoryczne. Nawet jeśli pozostają one na poziomie najlepszej strategii wygranej, to i tak gracz porządkuje świat nie według wektorowej matematyki a raczej własnych preferencji, pomysłowości i użyteczności elementów gry.

\section{Ruch w narracji}

Ruch, oprócz swojego związku z narracją, przynosi ze sobą czystą kinestetyczną przyjemność. Obojętne czy doświadcza się własnego ruchu, czy skupia się na mobilności innego przedmiotu, to zawsze jest on tak samo hipnotyzujący. Ten rodzaj doznania najlepiej opisuje, stworzona przez Rogera Caillois [1997, 30] ka- 
tegoria ilinx. Odnosi się ona do zabaw, które mają za zadanie oszołomić uczestnika. Sprawić, by na chwilę zatopił się w przyjemności zniekształconego odbioru rzeczywistości - czystej przyjemności bycia w ruchu i poczucia rzeczywistości całym sobą. Mogłoby się wydawać, że kategoria ta jest odpowiednia jedynie dla opisu wrażeń z różnego rodzaju karuzel lub dziecięcych zabaw, opierających się na doprowadzeniu uczestnika do zawrotów głowy, które skutecznie uniemożliwiają mu utrzymanie równowagi. Jednakże pomimo związków tego pojęcia z aktywnościami związanymi z przestrzenią fizyczną, to wydaje się, że można je odnieść również do dzisiejszych gier wideo.

Za sprawą współczesnych osiągnięć technologicznych gry coraz bardziej wpływają na nasze doświadczenie ich rzeczywistości w trakcie rozgrywki. Coraz bardziej wyrafinowana i realistyczna grafika oraz pomysłowe sposoby poruszania się w środowisku gry aktywnie wpływają na percepcję przestrzeni w grze. Ciekawym przykładem jest gra Mirror's Edge [EA DICE 2008], w której główną płaszczyzną poruszania się są dachy wieżowców. Faith, główna bohaterka gry, eksploruje przestrzeń miasta, posługując się ekstremalną zręcznością oraz zwinnością, w stopniu, który jest poza zasięgiem przeciętnego człowieka. Podczas eksploracji przestrzeni gry gracz, wspomagany przez immersyjną perspektywę pierwszoosobową, jest zmuszony porzucić swoje przyzwyczajenia związane z typowym poruszaniem się po mieście i naciągnąć podstawowe prawa fizyki oraz bariery własnej fizyczności. Wrażenie, które poprzez zastosowanie takiej mechaniki próbują wywołać twórcy, przypomina, przynajmniej w teorii, pierwotne doświadczenie ilinx, którego nie ogranicza cielesna nieobecność gracza w świecie gry.

Takie strategie eksploracji, wykorzystywane są obecnie w wielu produkcjach, które kładą duży nacisk na aspekt zręcznościowy gry (np. seria Assassin's Creed). Inspirowane są one głównie parkourem oraz freerunem, które zaczynają cieszyć się coraz większą popularnością wśród młodych mieszkańców miast. Parkour, i zrodzony z niego freerun, to ekstremalne formy aktywności fizycznej, które polegają na niekonwencjonalnej eksploracji zabudowy miejskiej. Obydwie skupiają się przede wszystkim na afirmacji poczucia wolności, które wyraża się w kreatywnym podejściu do samej koncepcji ruchu: przemieszczanie się z miejsca na miejsce nie tylko powinno być szybkie i efektywne, ale przede wszystkim widowiskowe. Osiągnięcie takie efektu jest możliwe tylko wtedy, gdy dochodzi do aktywnej kontemplacji architektury połączonej z reinterpretacją przestrzeni. Uruchomione w ten sposób mentalne mechanizmy wyzwalają w człowieku całą gamę emocji. Nie chodzi tutaj jedynie o uwolnioną adrenalinę, ale przede wszystkim o odsłonięcie afektywnego obrazu miasta. Można zatem 
zaryzykować stwierdzenie, że traceur $^{3}$ to uwspółcześniona wersja flâneura [Rawlinson i Guaralda 2012].

Kinestetyczna przyjemność płynąca z mobilności gracza, $\mathrm{z}$ dynamiki ruchów i ich widowiskowości, sprawia, że ten model eksploracji przestrzeni gry wideo wydaje się współcześnie najbardziej dominujący. Zdecydowana większość współczesnych produkcji skupia uwagę gracza na poszukiwaniu potrzebnych w danym momencie detali i struktur, które umożliwią mu płynną rozgrywkę. Reszta obiektów traktowana jest jak scenografia. Wypełnia ona przestrzeń, często tworząc niezwykłe krajobrazy, ale presja czasu i rozgrywki sprawia, że zwykle brakuje czasu na wystudiowaną kontemplację. Ruch przeżywa się dla samego poczucia kinestetycznej wolności i chociaż jest on związany bezpośrednio $\mathrm{z}$ rozwojem narracji, to jednak podczas gry mechanizm ten staje sie niewidoczny. Wydaje się jednak, że istnieje spora grupa graczy, która poszukuje rozgrywki pozwalającej na powolne doświadczanie przestrzeni i pisanie własnej narracji. W tym kontekście zdecydowanie łatwiej zrozumieć fenomen popularności gier eksploracyjnych, które dały się poznać szerszemu gronu odbiorców za sprawą komercyjnej wersji Dear Esther wydanej w 2012 roku przez niezależne studio The Chinese Room. Obok dynamicznego traucera, na drugim końcu przestrzennego doświadczenia odrodziła się postać flâneura.

\section{Miasto-poza-miastem, czyli flâneuryzm w wirtualnej przestrzeni pozamiejskiej}

Postać flâneura i pojęcie flâneuryzmu pojawiło się na już początku wieku XIX, ale zostało szerzej zinterpretowane i opisane dopiero przez Waltera Benjamina (1892 1940). Myśliciela zainspirowały paryskie pasaże, które były naturalnym środowiskiem dla spacerowicza, oraz twórczość Charlesa Baudelaire’a. Flâneura można krótko opisać jako „figurę modernistycznej podmiotowości ukształtowanej w wielkim mieście” [Paetzold 1998, 122]. Jest on uzależniony od wielkomiejskiego życia. Kocha przebywać w tłumie przechodniów, ale ma raczej ambiwalentny stosunek wobec nich. Przeżywa miasto w kinestetycznym ruchu, niesiony pragnieniem nowych podniet wizualnych. Paradoksalnie ruch sprawia, że jest obecny w przestrzeni, ale jednocześnie alienuje go z rzeczywistości. Flâneur mimo pragnienia wchłonięcia miasta i niemalże zespolenia się z nim, pozostaje obcy. Nigdy jednak nie może nasycić się do końca, ponieważ czar bogatych i strojnych wystaw sklepowych jest zbyt ulotny. Dlatego pragnąc coraz to nowych podniet estetycznych, krąży po labiryncie ulic spodziewając się nowych niespodzianek za każdym z zakrętów. Wędrówka ta ma aspekt emocjonalno-intelektualny

3 Traceur - osoba trenująca parkour. 
- spacerując niespiesznie zamyśla się nad nowoczesnością, studiując tłum [Paetzold, 123-126].

Gry eksploracyjne są takim właśnie niespiesznym spacerem po wirtualnej przestrzeni. Gracz nie jest atakowany niepotrzebną mechaniką. Istnieje jedynie sam ruch i spostrzegawczość. W tego typu tytułach również realizuje się akt chodzenia jako akt wypowiadania, o którym pisał de Certeau. Wypełnia się on jednak w inny sposób, niż w grach nastawionych na akcję. Gry eksploracyjne sprzeciwiają się koncepcji interakcyjnego świata, w którym gracz jest bogiem. Tutaj jest on jedynie gościem w przestrzeni, obserwatorem. Nie kolonizuje on świata gry, podporządkowując go swojemu panowaniu i własnym zasadom. Jego głównym zadaniem nie jest bycie zdobywcą, a raczej odkrywcą. Przestrzeń przemawia do gracza w ruchu, a on nie musi jej ujarzmiać, by ją odczytać. Szczególnie poetycką i wyjątkowo dosłowną realizacją tej metafory jest właśnie Dear Esther.

Dla niektórych graczy i krytyków Dear Esther jest przede wszystkim wirtualną powieścią epistolarną. Większość narracji opiera się na fragmentach listów pisanych i odczytywanych przez bliżej nieokreślonego Narratora do jego ukochanej Esther, która najprawdopodobniej zginęła w wypadku samochodowym. Cała historia zaczyna się w momencie, gdy gracz budzi się na brzegu jednej z wysp w rejonie Hebrydów i pierwszymi słowami jakie słyszy nie są słowa wyjaśnienia, a właśnie początek listu do Esther. Porzucony w obcej przestrzeni, jest właściwie pozostawiony sobie. Gra nic nie podpowiada i nie atakuje zbędnymi informacjami. Towarzyszy mu jedynie głos Narratora, z którym kontakt można nawiązać jedynie poprzez ruch w przestrzeni. Nie polega on jednak na nieustannym pośpiechu, a raczej spokojnym spacerze. Presja czasu nie istnieje. Gracz pozbawiony mapy, rozpoczyna powoli swoją wędrówkę z każdym krokiem ucząc się przestrzeni. Podobnie jak w mieście, gdzie:

(...) orientację zdobywa się nie za pomocą planu, adresu - jak pisze Beata Frydryczak (1998, s. 105) - lecz przez spacer, doświadczenie; tutaj każde odkrycie jest intensywne i kruche, może być powtórzone lub odtworzone jedynie przez pamięć pozostawionego w nas śladu.

Spacer ten jest rodzajem filozoficznej przechadzki, celebrowania przestrzeni i uwikłanej w niej własnej cielesności. Podczas takiej wędrówki zwraca się uwagę na szczegóły w kontekście całości - świat zostaje wprawiony w ruch [Symotiuk 1997, 108]. Gracz jak flâneur rozpoczyna swoją kontemplacyjną wędrówkę, z tą różnicą, że scenografia wielkomiejskiego życia została zastąpiona przez samotną, bezludną wy- 
spę. Oprócz towarzyszących mu pojedynczych tajemniczych cieni, nie znajdziemy tłumu przechodniów, ale mieszanka lęku, fascynacji i samotności pozostaje ta sama.

Wyspa jawi się tutaj jako gigantyczny pasaż handlowy, w którym poukrywane informacje - jak drogie towary - kuszą swoją zagadkową, metafizyczną opowieścią. Gracz - flâneur, nigdy nie będzie posiadaczem artefaktów, zbiera jedynie echa informacji zapisane w dźwiękach, porozrzucanych dokumentach, zdjęciach, wzorach chemicznych i cytatach z Biblii. W związku z tym krajobraz wyspy jest tak naprawdę przestrzenią estetyczno-emocjonalną, a jej najpiękniejszym elementem jest połączenie narracji z ruchem. Wraz z wędrówką gracza uruchamiane są kolejne fragmenty listów Narratora. Odtwarzane są losowo, przez co za każdym razem doświadczenie gry jest trochę inne, a przestrzeń zaskakuje nowością. Co więcej, nie wszystkie miejsca mogą zostać odnalezione podczas pierwszego przejścia gry. Dlatego z każdą kolejną grą powstaje inną opowieść, która skupia sie na innych aspektach historii i na różnych bohaterach.

Każdy krok odsłania kolejne fragmenty narracji. Poznajemy bliżej Esther, Jackobsona, pasterza z XVIII w., kartografa Donnelly’ego oraz Paula - kierowcę, który spowodował wypadek. Przede wszystkim jednak coraz bardziej zagłębiamy się w emocjonalność Narratora. Do fragmentów, które z początku są logiczne i zrozumiałe, w miarę upływu drogi wkrada się chaos. Fakty i fantazje mieszają się ze sobą, co sprawia, że coraz trudniej odróżnić, o kim mowa w kolejnych listach. I tak jak zmienia się narracja, zmienia się również sceneria. Przestrzeń odbija nie tylko tragiczną historię Narratora, ale i emocje, które się za nią kryją. Z każdym kolejnym fragmentem listu, każdym miejscem i każdym kolejnym krokiem emocje ukryte w przestrzeni gry, stają się równocześnie emocjami gracza. Gracz wtapia się w przestrzeń, przeżywając ją w sobie.

Wieloznaczność ta implikuje szereg możliwości interpretacyjnych nie tylko dla samej historii, ale nawet dla postaci gracza. Nie wiadomo, czy można go utożsamić z postacią Narratora, który poprzez pisanie listów próbuje pogodzić się ze stratą partnerki. Czy też może cała wyspa jest tak naprawdę projekcją świadomości pogrążonej w śpiączce Esther, przy łóżku której ukochany czyta napisane do niej listy. W tym wypadku gracz zostaje zaproszony do eksploracji prywatnej emocjonalnej przestrzeni, by w niej spróbować rozszyfrować, co tak na prawdę stało się tragicznej nocy. Staje się on w takim momencie kimś w rodzaju wyjątkowego gościa. Odarty z jakiejkolwiek wizualnej reprezentacji, nie może skryć się za postacią wirtualnego bohatera. Musi pozostać sobą i odbyć mozolną wędrówkę, której finał za każdym razem odgrywa się na szczycie masztu radiowego. Nie ma innego sposobu na opuszczenie wyspy: jeśli spróbuje pogrążyć się w morskie fale, głos Narratora przywoła go z powrotem z ciemności. W tym kontekście bardzo interesującym zjawiskiem są duchy, które pojawiają 
się na mgnienie oka w różnych częściach wyspy. Stojące na klifach, czekające w chacie, czy odbijające się w płomieniu świecy, są jak pozostawione, odciśnięte w przestrzeni ślady innych podróżnych, którzy zdążyli już przebyć tę samą drogę. Dzięki swojej wędrówce stali się fragmentem pamięci tego miejsca.

Ta niejasna rola gracza wydaje się być szczególnie charakterystyczna dla gier eksploracyjnych. Kontrolowana przez niego postać zdaje się być jakby poza głównym wątkiem fabularnym. Można ją oczywiście interpretować jako bezpośredniego uczestnika wydarzeń, ale zawsze mechanizm eksploracji przestrzeni sprawia, że ma on przede wszystkim status tymczasowego gościa. To paradoksalny stan, w którym z jednej strony jest się nieznajomym, a może nawet obcym, a z drugiej - częścią zagadki. Podobny zabieg spotykamy także w grze Gone Home, w której domyślnie wcielamy się w postać Kaitlin Greenbriar, która po zagranicznych wojażach przyjeżdża do domu rodziców, by znaleźć to miejsce całkowicie opuszczonym. Dopiero po dokładnym przeszukaniu pustego domostwa, gracz jest w stanie złożyć fragmenty opowieści w całość. Odkrywamy sekretny romans matki oraz prawdę o dzieciństwie ojca. Dominującą narracją jest jednak opowieść młodszej siostry, która w swoim pamiętniku zwierza się z uczucia jakim darzy szkolną przyjaciółkę i tłumaczy się, dlaczego postanowiła opuścić dom rodzinny i zacząć nowe życie. Nasze bycie w świecie - pod postacią Kaitlin - nie zmienia jednak tego, że wobec przestrzeni gry jesteśmy ciągle przybyszem z zewnątrz, który musi się jej dopiero nauczyć, wręcz odkryć ją na nowo. Zbieramy kawałki układanki, nie zdając sobie sprawy, że sami jesteśmy brakującym kawałkiem łączącym pozostałe w całość. W równym stopniu należymy do przestrzeni gry, co przychodzimy z zewnątrz.

W grach eksploracyjnych realizują się również założenia tak zwanej po-wolnej przestrzeni, w której pragnie się powrócić do „smakowania czasoprzestrzennej struktury świata jako podstawy ludzkiego doświadczenia” [Rewers 2008, 88]. Podczas planowania zagospodarowania terenu projektant bierze przede wszystkim uwage łączność z naturą, której człowiek jest integralną częścią. Nie przeciwstawia się jej, nie próbuje okiełznać, a raczej próbuje harmonijnie $\mathrm{z}$ nią współistnieć. W slow space panuje atmosfera wzniosłej nostalgii, która spowalnia tempo życia mieszkańców wielkich miast. Przestrzeń zostaje uwolniona od feerii pstrokatych reklam i nadmiaru wizualnych informacji. Jak pisze Rewers [tamże, 98]:

Mniej korków, mniej hałasu, mniej tłumu, mniej wulgarności, mniej spektakli, więcej ciszy, dystansu, spokoju to droga, po której minimaliści zmierzają do wzniosłych, po-wolnych miast. 
Doskonałym przykładem realizacji tego typu przestrzeni w grach wideo jest bez wątpienia produkcja Eda Key’a i Davida Kanaga - Proteus. Doświadczenie niespiesznej rozgrywki zamyka się tutaj w medytacyjnym spacerze po wyspie, znajdującej się w mitycznym czasie cykliczności pór roku. Estetyka pixel art w połączeniu z oniryczną muzyką elektroniczną tworzą środowisko gry, które chociaż estetycznie odległe od realistycznych trójwymiarowych przestrzeni gier głównego nurtu, nie daje poczucia obcości. Uproszczone przedstawienia drzew, skał, małych stworzonek czy spadających gwiazd, sprowadzające się do ferii pikselowych plam, paradoksalnie zbliżają gracza do uczucia obcowania z prawdziwą naturą. Jest to możliwe, ponieważ Proteus nie próbuje kopiować rzeczywistości w sposób realistyczny. W przestrzeni gry zostały uwiecznione same prototypy tych obiektów, co w połączeniu z możliwością w zasadzie nieskrępowanej eksploracji staje się właśnie wirtualnym odbiciem slow space.

Proteusa nie można ukończyć na skróty. Nie znajdziemy tam tajnych przejść, czy sekretnych strategii grania, które doprowadzą nas w ciągu kilku minut do finału rozgrywki. W dużej mierze właśnie na tym polega po-wolność kontaktu z jego przestrzenią. Każdy spacer jest doświadczeniem nowym i unikalnym. Całe środowisko jest generowana proceduralnie: przy każdej nowej rozgrywce, środowisko wyspy kształtowanie jest inaczej. Dlatego też zapis rozgrywki innej osoby nie odda doznania indywidualnego kontaktu z grą. Właśnie ta indywidualność rozgrywki, $\mathrm{w}$ połączeniu $\mathrm{z}$ brakiem widocznego interfejsu oraz ograniczeniem przepływu nadmiaru informacji, daje poczucie bezpieczeństwa, które pomaga nam w pełni przeżyć przestrzeń Proteusa.

Wirtualne eksploracyjne środowisko gry zostaje oczyszczone z nadmiaru mechanik: akrobatyczny bieg został spowolniony do kontemplacyjnego spaceru; nie znajdzie się tam błyszczących artefaktów oraz nie zdobędzie specjalnych osiągnięć. Gracz został pozostawiany sam na sam z przestrzenią, w której kolekcjonuje się jedynie odciśnięte w pamięci kruche znaczenia. I tak jak wędrówki flâneura to „gest kulturowy przeciwstawiający się funkcjonalizmowi i racjonalności” [Paetzold, 128], tak gry eksploracyjne przeciwstawiają się wizualnej przemocy nagromadzonych informacji i oczywistych znaczeń.

\section{Podsumowanie}

Miejskie strategie przeżywania przestrzeni z łatwością manifestują się w środowisku gier wideo - szczególnie tym trójwymiarowym. Ma to związek nie tylko z samą reprezentacją wizualną miasta, ale również podobnym doświadczeniem przestrzeni. Wydawać by się mogło, że w grach nastawionych na akcję nie ma miejsca na tak 
subtelne zjawiska jak flâneuryzm. Rozgrywka powinna być dynamiczna i zorientowana na jeden cel jakim jest wygrana. Tymczasem, coraz bardziej otwarte światy w grach, pozwalają graczowi realizować całkowicie odmienne strategie grania. Gracz w każdej niemal chwili może sprzeciwić się pierwotnym założeniom twórców gry i porzucić predefiniowany przebieg rozgrywki i tym samym podjąć próbę samorealizacji własnej wolności. Samodzielnie wyznaczając ramy eksploracji, staje przed wyzwaniem nie tylko reinterpretacji istniejących już w przestrzeni gry sensów, ale również poszukiwaniem i kreowaniem nowych, całkowicie własnych treści. Tworząc nowe sposoby przemierzania wirtualnej przestrzeni, często decyduje się nie realizować powierzonych mu misji i zadań. Skupia się wtedy na prostych z pozoru czynnościach, które wykorzystują ukryty w grze potencjał znaczeniotwórczy. Grając w Skyrim [Bethesda Game Studios 2011] nie musi podążać ścieżką rozwoju epickiego bohatera. Może spędzić wiele godzin na wypełnianiu i doskonaleniu zawodu kowala lub zostać wysoko wykwalifikowanym kupcem. Grając w serię Grand Theft Auto, nie musi on podążać za celami, jakie wyznacza mu skoncentrowana na przestępczym świecie fabuła, ale może po prostu zanurzyć się w miejskie życie. Sprzeciwiając się realizacji zaplanowanej przez twórców historii, gracz bardzo dosłownie może wcielić się w postać flâneura. Realizując tą strategię doświadczania przestrzeni może nie tylko pozwolić ponieść się tłumowi albo, jak pokazuje nam przykład serii Assassin's Creed, samej przyjemności ruchu i zmienić się w traceura. Wszystkie tego typu zachowania są możliwe szczególnie w grach z otwartym światem. Konstrukcja przestrzeni gier takich jak wspomniany przeze mnie Skyrim, czy seria GTA zaprasza użytkowników, by dowolnie wybierali swoją drogę prowadzącą do odkrycia ich tajemnic. Pomimo obecności w środowisku gry, afordancje te nie zawsze są dla takiej przestrzeni gry pierwotnie zaplanowane przez twórców. Dopiero świadoma decyzja gracza pozwala im się zrealizować. Wydaje się, że właśnie tutaj tkwi główna różnica pomiędzy grami zorientowanymi na akcję a tymi eksploracyjnymi. Gracz sam decyduje, jaką pozycję w grze przyjmuje. Wydaje się, że w przypadku gier eksploracyjnych zjawisko flâneuryzmu jest domyślnie wpisane w ustawienia przestrzeni. Jest cechą charakterystyczną, która wyróżnia te produkcje na tle innych. Gracz zostaje wrzucony w przestrzeń, która w pierwszej kolejności zachęca go właśnie do tego typu zachowań. Oczywiście to ciągle od gracza zależy, czy podejmie tę grę ze światem, czy też zdecyduje się ją zarzucić. Jego status pozostaje jednak zasadniczo bez zmian. Bardziej niż zdobywcą będzie przede wszystkim gościem, który podczas spaceru nie kolekcjonuje kolejnych osiągnięć a raczej znaczenia. 


\section{Bibliografia}

Caillois, Roger. 1997, Gry i ludzie, przeł. Anna Tatarkiewicz, Maria Żurowska, Warszawa: Volumen.

Certeau, Michel de. 2008, Wynaleźć codzienność. Sztuki działania, przeł. Katarzyna Thiel-Jańczuk, Kraków: Wydawnictwo Uniwersytetu Jegiellońskiego.

Dovey, Jon, Kennedy, Helen W. 2011, Kultura gier komputerowych, Kraków: Wydawnictwa Uniwersytetu Jagiellońskiego.

Frydryczak, Beata. 1998, Okiem przechodnia: ulica jako przestrzeń estetyczna, w: J. S. Wojciechowski, A. Zeidler-Janiszewska (red.), Formy estetyzacji przestrzeni publicznej, Warszawa: Instytut Kultury, s. 101-115.

Jenkins, Henry. 2004, Game design as narrative architecture, w: First Person: New Media as Story, Performance, and Game, red. N. Wardrip-Fruin, P. Harrigan, Cambridge, MA: MIT Press.

Lynch, Kevin. 1960, The Image of the City, Cambrige/Massachsetts/London: The MIT Press.

Nitsche, Michael. 2008, Video Game Spaces. Image, Play, and Structure in 3D Game Worlds, Cambridge/Massachusetts/London: The MIT Press.

Paetzold, Heinz. Polityka przechadzki. Flâneur Benjamina i potem, tłum. E. Mikina, w: Formy estetyzacji przestrzeni publicznej, red. J. S. Wojciechowski, A. Zeidler Janiszewska, Warszawa 1998, s. 117-129.

Rawlinson, Christopher J., Guaralda, Mirko. Chaos and creativity of play: designing emotional engagement in public spaces, 2012, \{pilk PDF; dostęp offline: 8 VIII 2013\}

Rawlinson, Christopher, Guaralda, Mirko. 2012, Chaos and creativity of play: designing emotional engagement in public spaces, w: Out of control: Proceedings of 8 th International Design and Emotion Conference: Out of Control, red. J. Brassett, P. Hekkert, G. Ludden, M. Malpass, J. McDonnell, Janet, University of the Arts London, Central Saint Martins College of Art \& Design, London, United Kingdom, pp. 1-12.

Rewers, Ewa. 2008, Po-wolna przestrzeń, w: Krystyna Wilkoszewska (red.), Czas przestrzeni, Kraków: Towarzystwo Autorów i Wydawców Prac Naukowych Universitas.

Symotiuk, Stefan. 1997, Filozofia i genius loci, Warszawa: Instytut Kultury.

Yi-Fu Tuan. 1987, Przestrzeń i miejsce, przeł. A. Morawińska, Warszawa: Państwowy Instytut Wydawniczy. 


\section{Ludografia}

Ubisoft Montreal, 2007-2013, seria Assassin's Creed [PC], Ubisoft.

The Chinese Room, 2012, Dear Esther [PC], The Chinese Room.

The Fullbright Company, 2013, Gone Home [PC], The Fullbright Company.

Rockstar North, 1997-2015, seria Grand Theft Auto [PC], Rockstar Games.

EA Digital Illusions CE, 2008, Mirror's Edge [PC], Electronic Arts.

Ed Key and David Kanaga, 2013, Proteus [PC], Ed Key and David Kanaga.

Bethesda Game Studios, 2011, The Elder Scrolls V: Skyrim [PC], Bethesda Softworks.

\section{Summary}

City beyond the city: the notion of contemporary flaneurism in video games This article is a comparative analysis between the exploration video game genre and the theories of contemporary city space. It focuses predominantly on confronting spatial experience of the city space with video game space. This comparison uses the concept of flâneur and slow space to show how these two phenomena are manifested in virtual environments. In the exploration video games, such as Dear Esther and Proteus, the author sees an interesting alternative to overcomplicated gameplay and games overloaded with unnecessary visual information.

Keywords: exploration video game, city space, flâneur, slow space, video game space, motion in video games

mgr Justyna Janik - doktorantka w Instytucie Sztuk Audiowizualnych Uniwersytetu Jagiellońskiego. Kulturoznawca z wykształcenia - medioznawca i groznawca z zamiłowania. Naukowo zajmuje się przede wszystkim kulturą fanowską oraz game studies, szczególnie takimi zagadnieniami jak posthumanizm, estetyka oraz relacja gracza $\mathrm{z}$ grą wideo. 